\title{
Genetic Differentiation, Mating Systems and Crossability of Three Floral Variants of Sandalwood (Santalum album L.) in Gunung Sewu Geopark, Indonesia
}

\section{Sapto Indrioko and Yeni Widyana Nurcahyani Cahyaningrum}

Forest Tree Improvement Laboratory, Faculty of Forestry, Universitas Gadjah Mada, Jl. Agro No.1, Sleman, Yogyakarta 55281, Indonesia

\section{Abstract}

Despite the degradation in their origin in the south-eastern islands of Indonesia, sandalwood (Santalum album L.) recently occurs as new landraces in Gunung Sewu Geopark, Java island, Indonesia. All of the landraces consisted of three floral variants (YBF, refers to 'yellow big flower'; RBF, 'red big flower'; and RSF, 'red small flower,' respectively), which were differed in floral structures. Isoenzymes and hand-pollination

Corresponding Author:

Sapto Indrioko

sindrioko@ugm.ac.id

Received: 10 November 2018

Accepted: 6 January 2019

Published: 10 March 2019

Publishing services provided by Knowledge E

(c) Sapto Indrioko and Yeni Widyana Nurcahyani

Cahyaningrum. This article is distributed under the terms of the Creative Commons.

Attribution License, which permits unrestricted use and redistribution provided that the original author and source are credited.

Selection and Peer-review under the responsibility of the UASC Life Sciences 2016 Conference Committee. treatments were combined to analyze whether these variants have different genetic diversity, mating systems, and crossing ability. Observed heterozygosity varied significantly with sites $\left(\mathrm{H}_{O} 0.021\right.$ to 0.327$)$. A moderate level of diversity was maintained among sites $\left(\mathrm{H}_{S} 0.200 ; \mathrm{H}_{T} 0.265 ; \mathrm{D}_{S T}=6.5 \% ; \mathrm{G}_{S T}=24.41 \%\right)$. Clonalized populations exhibited a much lower level of heterozygosity and inbreeding. However, heterozygosity among floral variants was similar $\left(H_{O} 0.227\right.$ to 0.279$)$. Reproductive Success among both floral variants and populations was also insignificant. However, a significant Reproductive Success was observed among hand pollination treatments. The highest Reproductive Success was achieved from inter-specific cross-pollinated flowers for all variants. Very low RS were observed in the intra-specific cross-pollination. The RSF variant was incompatible at any of cross-pollination treatments. Mature fruits were only gained from the reciprocal cross-pollination of $\mathrm{YBF} \times \mathrm{RBF}$ variants. Populations with higher heterozygosity and outcrossing rate failed to produce seeds in hand-self pollination. Maintaining the evolutionary processes within each population should be carried out with a different strategy according to the genetic diversity, degree of clonality and the composition of floral variants in the population.

Keywords: Crossability, Floral variants, Genetic differentiation, Gunung Sewu Geopark, Mating systems; Sandalwood.

\section{Introduction}

Many species showed evidence of genetic structuring, particularly when there are physical barriers to dispersal [1-3] and mating constraints [4, 5]. Physical barriers may exist 
between regions as the presence of natural barriers such as mountains, valleys, cliffs or oceans that lead to the restriction of gene flow [1-3] or may also be caused by habitat fragmentation due to anthropogenic disturbances $[5,6]$. In such a case, genetic differences occurred as a result of different patterns of allele frequency distribution between populations [2]. In other cases, genetic differentiation may exist as a result of mating barriers due to the differences on the floral structures and biology [5,7-9] among individuals within a population, that in turn lead to a mating incompatibility [4, 5]. In such cases, reproductive failure could more be attributed to the mating barrier of pollination due to the differences on stylus length [9], structures of the corolla, filament length, stigma-anthers position [7], pistil dysfunction, male sterility [5] and / or asynchrony on sexual organs maturity [8].

Distributed naturally along China, India, Indonesia and The Philippines [10], an economic-important species Santalum album L. (Santalaceae)-formerly called sandalwood-has been categorized as threatened species due to its significant degradation and / or habitat loss caused by demand on its wood and oil [4]. Its heartwood, containing $1.5 \%$ to $5 \%$ of $\beta$-santalol-a strong-specific fragrance of oil-is widely used for wood carving, religious and medicinal purposes. Its oil has been used as materials for cosmetics, prime sources of perfumes and aroma therapy, and was presumed to contain anti-melanoma compounds [4, 11]. Recently, this species found to be extinct in the wild in most of its native in Eastern parts of Indonesia [12].

Despite a significant degradation in its origin in the South-eastern islands of Indonesia, new landraces of sandalwood emerged in Gunung Sewu Geopark, a 1300 km² mountainous limestone zones in the central part of Java island, Indonesia. The oldest sandals' herbarium specimen (dated by the year 1853) in Java island was found in Imogiri District, and another specimen (dated by the year 1960) was collected from Nglipar District; both were part of Gunung Sewu Geopark. Previously, geographical events which were started from about $1.8 \times 10^{6} \mathrm{yr}$ ago-involved tectonic movements, volcanic activities, and seawater erosion-has derived this area into various landscape structures differed in altitude, elevation, soils and microclimate conditions [13, 14]. Considering a rapid degradation of sandalwood population in its origin, the occurrence of new landraces in Gunung Sewu may provide a promising source for any of reintroduction and rehabilitation efforts.

Many studies showed clear evidence that differences in floral structures may affect the mating systems $[15,16]$, which in turn resulted in different pollination success and reproductive outputs [5-9]. Furthermore, the differences on floral sexual organs may 
affect pollen-pistil interaction which in turn resulting in interspecific-mating incompatibility, as reported for S. album in India [17], S. album, S. Ianceolatum and S. spicatum in Western Australia [18] and S. Ianceolatum in Victoria Australia [5]. Sandalwood in Gunung Sewu occurred in various types of landscapes; some of them were bordered by natural barriers such as dense woody forests and rocky limestone walls. Beside of these physical barriers, sandalwood in Gunung Sewu tended to experience mating constraints since some of the population failed to produce mature fruits. Each population in Gunung Sewu consisted of at least three sandal variants that were distinguished by their floral and leaves structures. The preliminary study divided these variants into three groups (YBF, refers to "yellow big flower"; RBF, "big red flower"; and RSF, "red small flower," respectively), which were differed in floral structures and longevity. These differences were considered to be under genetic controls, while the variation among sites was affected more by environmental differences. In order to arrange the geneticallybased conservation strategy, this previous finding recommended further investigation of genetic differences and crossing abilities among variants. In this study, the study combined field observations, hand-pollination with biochemical marker-gene analysis to compare genetic diversity, mating systems and cross ability of three sandals variants among four populations representing geographical zones in Gunung Sewu Geopark, Indonesia.

\section{Materials and Methods}

\subsection{Study sites}

Gunung Sewu consisted of more than ten sandalwood populations in the form of both planted and naturally regenerated stands. However, study sites only compared four populations which were representing distinctively different population structures: one of population (the basin of Bleberan) in the Middle Zone, two (the highland of Nglanggeran and the lowland cave of Bejiharjo) in the Northern Zone, and one (the karst area Petir) in the Southern Zone, respectively. Each of population is separated by $25 \mathrm{~km}$ to $40 \mathrm{~km}$. These sites are at different altitude, experienced different climatic regimes and having clear ecological differences (Table 1; Fig. 1). 


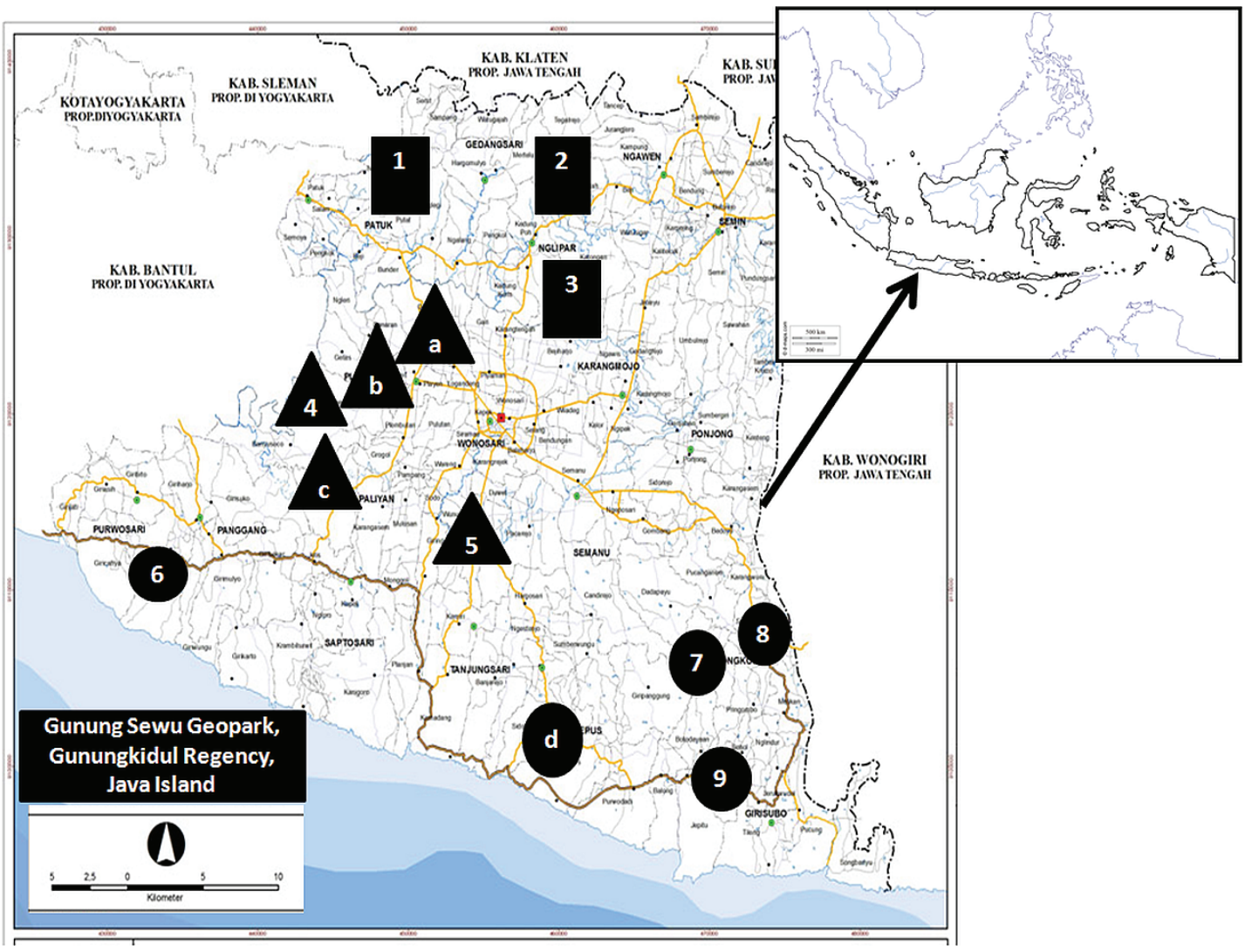

Figure 1: Study sites: sandalwood populations in the Gunung Sewu Geopark, Gunungkidul Regency, Java island. The first group (Northern Zone): Nglanggeran (1), Sriten (2) and Bejiharjo (3); the second group (Middle Zone): Bunder (a), Wanagama (b), Banyusoco (c), Bleberan (4), and Ngingrong (5); and the third group (Southern Zone): Pucanganom (6), Petir (7), Semugih (8), Botodayakan (9) and Tepus (d) populations, respectively. The arabic numbers represent natural landraces, while the alphabetic fonts represent ex situ conservation areas, respectively. Within each Gunung Sewu zone, sandalwood populations are marked by squares (Northern Zone), triangles (Middle Zone) and circles (Southern Zone) shapes, respectively. Study was carried out on Nglanggeran (1), Bejiharjo (3), Bleberan (4), and Petir (7) populations which were representing each of geographical zones.

\subsection{Study species}

Sandalwood is a long-lived, yearly flowering perennial of semi-arid and tropical region throughout south-eastern and middle parts of Indonesia. It is a shrub attaining a height of about $12 \mathrm{~m}$ and a girth of $10 \mathrm{~cm}$ to $30 \mathrm{~cm}$ [4, 11], mainly vegetatively reproduced by root suckers $[3,5,6,11,19]$, particularly under marginal condition. Generally, sandalwood in Indonesia flowered twice a year: at the beginning of dry season in May to September, and at the beginning of rainy season in November to March; with 4 mo to 5 mo flowering period [20, 21]. Flowers pollinated by insects belong to hymenopterans, lepidopterans and dipterans [16, 25]. The previous study showed evidence of dichogamy [21], highly outcrossing rate and self-incompatibility $[3,5,11,12]$. However, partially self-compatibility has been reported for S. accuminatum [5] and S. album [21, 23], particularly under isolated condition. Santalum has strong ability to produce root suckers; the vegetatively 
TABLE 1: Population structures and the habitat characteristics of study sites.

\begin{tabular}{|c|c|c|c|}
\hline $\begin{array}{l}\text { Population, } \\
\text { width, altitude, } \\
\text { climatic types }\end{array}$ & $\begin{array}{l}\text { Landscape history } \\
\text { and present habitat } \\
\text { characteristics }\end{array}$ & $\begin{array}{l}\text { Soil and rock } \\
\text { units }\end{array}$ & $\begin{array}{l}\text { Sandalwood history and present } \\
\text { population characteristics }\end{array}$ \\
\hline $\begin{array}{l}\text { GSN1- } \\
\text { Nglanggeran; } 79.3 \\
\text { ha; } 710 \mathrm{~m} \text { to } 750 \mathrm{~m} \\
\text { asl; } A m \text { type }\end{array}$ & $\begin{array}{l}\text { A part of Nglanggeran } \\
\text { Formation, Northern } \\
\text { Zone of Gunung Sewu. } \\
\text { Now existed as the } \\
\text { mountainary } \\
\text { landscapes, strong } \\
\text { undulating, } \\
\text { characterizing tropical } \\
\text { mountain ecosystems. }\end{array}$ & $\begin{array}{l}\text { Latosols with } \\
\text { volcanic and } \\
\text { sediment rocks, } \\
\text { some with deeper } \\
\text { solum. }\end{array}$ & $\begin{array}{l}\text { Sandalwood was first documented } \\
\text { in } 1970 \text { 's. Recently occured in groups } \\
\text { of stands across the Nglanggeran } \\
\text { mountain regions, in association with } \\
\text { the tropical mountain vegetation. } \\
\text { Habitat dominated by the } \\
\text { association of naturally regenerated } \\
\text { mahogany, Gliricidea sp, and several } \\
\text { Garcinia and Eugenia families. }\end{array}$ \\
\hline $\begin{array}{l}\text { GSN3-Bejiharjo; } \\
9.6 \text { ha; } 150 \mathrm{ml} \text { to } \\
180 \mathrm{~m} \text { asl; } A w \\
\text { type }\end{array}$ & $\begin{array}{l}\text { A part of Sambipitu } \\
\text { Formation, Northern } \\
\text { Zone of Gunung Sewu. } \\
\text { Now existed as the } \\
\text { open dry-rocky hilly } \\
\text { landscapes with caves } \\
\text { and ground-rivers } \\
\text { below. Representing } \\
\text { the dryland } \\
\text { ecosystems. }\end{array}$ & $\begin{array}{l}\text { The association of } \\
\text { red mediterrans } \\
\text { and black } \\
\text { grumosols with } \\
\text { limestone rocks, } \\
\text { mostly with the } \\
\text { shallow solum }\end{array}$ & $\begin{array}{l}\text { Sandalwood is a remnant of the } \\
1970 \text { 's planted stands. Fragmented } \\
\text { due to heavy exploitation, urban and } \\
\text { cave-tourism activities since 1990's. } \\
\text { Now existed as a small-fragmented } \\
\text { group of stands, dispersely occured } \\
\text { in an open dry-rocky hills above the } \\
\text { caves and ground-rivers. } \\
\text { Sandalwood grew in an association } \\
\text { with cajuputi and acacia regenerated } \\
\text { from commercial plantation nearby. } \\
\text { Younger sandal trees were largely } \\
\text { derived from root suckers. Sites } \\
\text { dominated by dryland herbs such as } \\
\text { grasses and Eupatorium sp. }\end{array}$ \\
\hline $\begin{array}{l}\text { GSM1-Bleberan; } \\
52.9 \text { ha; } 150 \mathrm{~m} \text { to } \\
170 \mathrm{~m} \text { asl; } \\
\text { intermediate } \\
\text { between } A w \text { and } \\
\text { Am type }\end{array}$ & $\begin{array}{l}\text { A part of Wonosari } \\
\text { Basin Formation, } \\
\text { Middle Zone of } \\
\text { Gunung Sewu. Now } \\
\text { existed as the } \\
\text { catchment area of the } \\
\text { ancient subterranean } \\
\text { Oya River at the } \\
\text { lowland basin } \\
\text { landscapes. } \\
\text { Representing the } \\
\text { tropical lowland } \\
\text { ecosystems. }\end{array}$ & $\begin{array}{l}\text { The association of } \\
\text { red mediterrans } \\
\text { and black } \\
\text { grumosols with } \\
\text { limestone rocks, } \\
\text { mostly with the } \\
\text { deeper solum. }\end{array}$ & $\begin{array}{l}\text { Sandalwood was first documented } \\
\text { in } 1970 \text { 's along the catchment area } \\
\text { of the ancient subterranean Oya } \\
\text { River, at the lowland basin of middle } \\
\text { zone. Sandalwood dispersed widely } \\
\text { along the riparian catchment area } \\
\text { and nearby, in association with the } \\
\text { tropical lowland forest vegetation } \\
\text { which is consisted of more diverse } \\
\text { vegetation including teak, } \\
\text { mahogany, Gliricidea sp, Schleicera } \\
\text { sp, cajuputi and acacia. Population is } \\
\text { surrounded by several ex situ } \\
\text { conservation areas which are } \\
\text { sharing the same river. }\end{array}$ \\
\hline $\begin{array}{l}\text { GSS1-Petir; } 78 \text { ha; } \\
70 \text { m to } 100 \text { m asl; } \\
\text { Aw type }\end{array}$ & $\begin{array}{l}\text { A part of } \\
\text { Wonosari-Punung } \\
\text { Karst Formation, } \\
\text { Southern Zone of } \\
\text { Gunung Sewu. Now } \\
\text { existed as the karst } \\
\text { hilly landscapes with } \\
\text { open dry-rocky hills, } \\
\text { strong undulating, } \\
\text { characterizing the dry } \\
\text { rocky-limestone } \\
\text { ecosystems. }\end{array}$ & $\begin{array}{l}\text { Latosols with } \\
\text { limestone rocks. } \\
\text { Solum is deeper } \\
\text { at the basins, but } \\
\text { very shallow at } \\
\text { the } \\
\text { limestone-rocky } \\
\text { hills. }\end{array}$ & $\begin{array}{l}\text { Sandalwood was first documented } \\
\text { in } 1960 \text { 's in karst hilly areas, recently } \\
\text { covering more than twenty open } \\
\text { dry-rocky hills. Adult plants were } \\
\text { mostly derived from root suckers; } \\
\text { highly clonalized. In the } \\
\text { open-undulating areas, sandalwood } \\
\text { grew in association with dry } \\
\text { rocky-limestone vegetation including } \\
\text { acacia and cajuputi, but more } \\
\text { dominated by shrubs and herbs } \\
\text { such as grasses and Eupatorium sp. }\end{array}$ \\
\hline
\end{tabular}


$[3,5,6]$. Previous researches documented pollen limitation due to less pollen production $[16,18]$ and male sterility [5]. Its reproductive success was also very low, ranging from $0.03 \%$ in natural population to less than $20 \%$ in ex-situ plantation [21], however, crosspollination tended to enhance seed set [11].

The preliminary study divided sandalwood in Gunung Sewu into three variants (YBF, refers to "big yellow flower"; RBF, "big red flower"; and RSF, "red small flower," respectively) differed by floral structures. RSF and RBF dominated by red and maroon colors, while YBF is more yellowish to orange. RBF and YBF possessed bigger perigonium, longer sexual organs but with shorter longevity, and similar/lower position of the stylus to stamens. RSF flowers are the smaller, similar/higher position of the stylus and longer longevity. RSF produced more flowers per inflorescence. Sandalwood flowered twice a year in all of sites and variants, however, the onset and duration varied. YBF flowered earliest while RBF was the latest. RSF possessed the longest flowering period. Flowering differences among variants were considered to be under genetic controls, while the variation among sites was affected more by environmental differences. Flowering varied among sites due to the altitude, soils and climatic differences. Sandalwood in lower altitude, drier and warmer sites flowered earlier and shorter.

\subsection{Population structure measurements}

Measurements in early 2016 were made to determine the population width and size $[5,23]$. Populations were defined as spatially discrete clusters of plants, separated from others by at least $500 \mathrm{~m}$ [24]. A $10 \mathrm{~m} \times 10 \mathrm{~m}$ grid was made on each of 1 ha of width, where the number of individuals was counted [4]. Measurements in effective population size as the number of flowering individuals divided by the total number of adult individuals [25]. Population density conformed to the number of single individuals per ha [23]. To measure the extent of clonality, it will be counted the proportion of vegetatively vs. reproductively propagated individuals within each of populations. Visibly separated stands [5] which have different vegetative and sexual organs morphology [1] were regarded as an individual, whereas stem separated by less than $10 \mathrm{~cm}$ [5] and/or shared the same root systems [23] were regarded as part of the same individual. Individual maturity determined by the presence of flowering [5, 23]. 


\subsection{Hand-pollination treatments and reproductive parameters mea- surements}

The degree of cross- and self-compatibility was assessed over the 2016's flowering period by performing hand pollination experiments: i) hand self-pollination; ii) hand crosspollination; and iii) natural open pollination [26]. To support cross-pollination, filaments were emasculated at anthesis to remove immature anthers. Receptive stigma was pollinated by a selected pollen source (male parent) by applying the mature anther to the stigma in 3 times replication to ensure the pollen transfers. Each inflorescence was then tagged and isolated using fine fabrics. To perform self-pollination, single inflorescence was isolated using fine fabrics prior to anthesis. Hand pollination was conducted in four populations (total $\mathbf{N}$ for self hand-pollination = 279 single flowers in Nglanggeran, 551 in Bejiharjo, 301 in Bleberan, and 303 in Petir; $\mathrm{N}$ for open pollination = 257 single flowers in Nglanggeran, 405 in Bejiharjo, 214 in Bleberan, and 209 in Petir; N for cross handpollination $=300$ in each population). These four sites represented each of the geographical zones in Gunung Sewu. To measure reproductive success of the seed sets, the flowers and mature seeds were counted and the value of Reproductive Success (RS) correspond to the ability of reproductive organs to form mature seeds-was measured following the formula, RS $=($ Fruit/Flower $) \times($ Seed/Ovule $)$.

\subsection{Isozyme analysis}

Genetic diversity was measured spatially across four populations along geographical gradients in Gunung Sewu. To measure genetic diversity of parents, at the end of rainy season in June 2016, juvenile leaves were sampled from randomly chosen individuals. In order to avoid the re-sampling of the same siblings, particularly at the strongly clonalized populations, it supposed to be ensured that the sampled trees were propagated from sexual reproduction. The flowering trees were of the first priority to be sampled. Samples were wrapped, frozen in ice packs and taken to the laboratory for allozyme extraction and electrophoresis. Previous study gained three enzymes, shikimate dehydrogenase (E.C. 1.1.1.25.), esterase (E.C. 3.1.1.) and diaphorase (E.C. 2.6.4.3.) which observed to be polymorphic. Zymogram phenotypes that were interpretable were found for only six loci, shikimate dehydrogenase Skd-1, esterase Est-1, Est-2, and Est-3, and diaphorase Dia-1 and Dia-2. Electrophoretic procedures were conducted with vertical polyacrilamide gel electrophoresis procedures following David-Ornstein method [27]. The leaves were homogenized in modified extraction buffer and centrifuged at $1570.78 \mathrm{rad} / \mathrm{sec}$ for 15 min at $4{ }^{\circ} \mathrm{C}$. The supernatant was loaded onto polyacrylamide vertical slab (Sigma Inc., 
USA) gels and electrophoresed at $4{ }^{\circ} \mathrm{C}$ at $220 \mathrm{~V}$ and $200 \mathrm{~mA}$ current for about $3 \mathrm{~h}$. After electrophoresis, the gels were stained using staining solution of each enzyme system, and the allozyme gels were genetically interpreted.

At each of the allozyme locus, the frequency of each allele and the genotype were counted. For each locus the number of heterozygote genotype were counted and expressed as percent observed heterozygosity $\left(\mathrm{H}_{o}\right)$. The observed heterozygosity was then pooled and averaged over all loci to determine the percent observed heterozygosity for a population. The expected heterozygosity $\left(\mathrm{H}_{e}\right)$ for each locus and over all loci for each population in Hardy-Weinberg equilibrium was counted following the formula: $\mathrm{H}_{e}=$ $1-\Sigma \mathrm{p}_{i}{ }^{2}$, where $\mathrm{p}_{i}$ refers to the i's allele frequency of a given population. Total population heterozygosity $\left(\mathrm{H}_{T}\right)$ was counted following the formula: $\mathrm{H}_{e}=1-\Sigma \mathrm{p}_{i t}{ }^{2}$, where $\mathrm{p}_{i t}$ refers to the i's allele frequency of the populations in total. Fixation index, the deviation from expected frequencies under Hardy-Weinberg equilibrium, was measured following the formula: $\mathrm{F}_{i s}=1-\mathrm{H}_{o} / \mathrm{H}_{e}$. To measure genetic differentiation, genetic diversity between populations $\left(\mathrm{D}_{S T}\right)$ was calculated by reducing the value of total heterozygosity $\left(\mathrm{H}_{T}\right)$ to heterozygosity within population $\left(\mathrm{H}_{S}\right)$. The mean proportion of total gene diversity at polymorphic loci due to differences between populations $\left(G_{S T}\right)$ was measured by dividing $\mathrm{D}_{S T}$ to $\mathrm{H}_{T}$.

\subsection{Statistical analysis}

Test of analysis of variance (ANOVA, LSD test) performed among parameters within populations and within floral variants. ANOVA was conducted to determine differences on the population structures, observed heterozygosity and fixation index among sites and among floral variants. ANOVA was also conducted in determining the differences of Reproductive Success resulted from different hand-pollination treatments, among floral variants, and among sites. Similar analyses were conducted to examine the differences between intra- and inter-specific outcrossed hand-pollination, and the differences among each of floral variants as the female parent. Multiple linear regressions based on population size and degree of clonality were carried out to examine the relationship between the population structures and the predictor variables observed heterozygosity $(\mathrm{Ho})$ and inbreeding coefficient (FIS). The same method was applied to estimate the effect of both parental observed heterozygosity $(\mathrm{Ho})$ and parental inbreeding coefficient (FIS) to the offspring heterozygosity and seedling recruitments. Some of the variables were subjected to logarithmic transformation to obtain normal data distributions. For the multiple regression analysis, a backward stepwise procedure was applied, with the 
final model including only variables with a significant $(p<0.05)$ effect on the dependent variable. All statistical analyses were carried out with SPSS (Version 16.0, SPSS Inc.).

\section{Results}

\subsection{Isozyme analysis}

\subsubsection{Allele frequency and distribution}

Six loci showed considerable polymorphism (Est-1, Est-2, Est-3, Dia-1, Dia-2, and Skd1) in most of populations, except Petir in which Dia-1 loci is monomorphic. These loci were also polymorphic in most of flower variants, except YBF in which many of loci are monomorphic. The YBF variant possessed monomorphic loci for Est-2 in Bleberan and Nglanggeran site, and for Dia-1 in Petir. In Bejiharjo, all of loci, except Dia-1, were monomorphic for YBF variant. However, the monomorphic loci of each variants were differed with sites. In Petir, most of monomorphic loci (Est-2, Est-3, and Dia-1) occurred in RBF. While in Nglanggeran, the Est-2 loci was monomorphic for YBF and RSF variants. Allele distributions differed with floral variants. The high frequency of "c" allele of Dia-1, which was considered rare at any of sites and variants, was occurred in YBF variant at all sites. In Skd-1, allele "a" dominated the RBF and RSF variants, while those of YBF was dominated by allele "c" (data not shown).

\subsubsection{Heterozygosity and fixation index}

Observed heterozygosity varied significantly with sites (Ho 0.021 to 0.327 ; F stat. 0.008 , $P$ value 8.016; respectively). A moderate level of diversity was maintained among sites $\left(\mathrm{H}_{S} 0.200 ; \mathrm{H}_{T} 0.265 ; \mathrm{D}_{S T}=6.5 \% ; \mathrm{G}_{S T}=24.41 \%\right.$, respectively). In this study, populations which experienced heavy exploitation and/or grew on marginal-rocky conditions were more clonalized. They existed as genotypically-identical parent trees, and recruited individuals mostly by root suckers. In general, the more clonalized populations exhibited much lower level of heterozygosity and tended to be more inbreeder. The $\mathrm{F}_{I S}$ values, which represented the parental inbreeding coefficient, were also differed among sites in line with the differences on heterozygosity and degree of clonality. Of the four populations (each consisted of three variants) tested for conformity to Hardy-Weinberg equilibrium, only the most clonalized ones (Petir and Bejiharjo) showed a significant departure due to an excess of homozygotes, indicating a very high level of parental inbreeding. In general, the more clonalized populations exhibited much higher level of 
parental inbreeding, and lower level of heterozygosity. However, there was no significant differences on heterozygosity among floral variants $\left(\mathrm{H}_{O} 0.227\right.$ to $0.279 ; \mathrm{F}$ stat. $0.787, \mathrm{P}$ value 0.246 ; respectively). Some of diversity was maintained among variants $\left(\mathrm{H}_{S} 0.248\right.$; $\mathrm{H}_{T} 0.265 ; \mathrm{D}_{S T}=1.7 \% ; \mathrm{G}_{S T}=6.45 \%$, respectively) (Table 2).

TABLE 2: Population structures and genetic parameters measurements among sandalwood populations and floral variants.

\begin{tabular}{|c|c|c|c|c|c|c|c|c|c|c|}
\hline \multirow{2}{*}{$\begin{array}{l}\text { Population and floral } \\
\text { variants }\end{array}$} & \multicolumn{3}{|c|}{ Population structures } & \multicolumn{7}{|c|}{ Genetic parameters } \\
\hline & $\begin{array}{l}\text { Flowered } \\
\text { indiv. }\end{array}$ & $\begin{array}{l}\text { Sampled } \\
\text { indiv. }\end{array}$ & $\begin{array}{c}\text { Clonality } \\
\text { (\%) }\end{array}$ & $\mathbf{H}_{E}$ & $\mathbf{H}_{O}$ & $\mathbf{F}_{I S}$ & $\mathbf{H}_{S}$ & $\mathbf{H}_{T}$ & $\mathbf{D}_{S T}$ & $\mathbf{G}_{S T}$ \\
\hline \multicolumn{11}{|l|}{ Among populations } \\
\hline \multicolumn{11}{|l|}{ Nglanggeran } \\
\hline - Red-big flower var. & $57^{a}$ & 57 & $0^{a}$ & $0.310^{c}$ & $0.281^{c}$ & $0.095^{b}$ & & & & \\
\hline - Yellow-big flower var. & $56^{a}$ & 56 & $0^{a}$ & $0.282^{c}$ & $0.244^{c}$ & $0.134^{b}$ & & & & \\
\hline - Red-small flower var. & $28^{a}$ & 28 & $0^{a}$ & $0.211^{b}$ & $0.268^{c}$ & $-0.269^{a}$ & & & & \\
\hline \multicolumn{11}{|l|}{ Bejiharjo } \\
\hline - Red-big flower var. & $47^{a}$ & 44 & $6.38^{a}$ & $0.144^{b}$ & $0.114^{b}$ & $0.204^{c}$ & & & & \\
\hline - Yellow-big flower var. & $14^{a}$ & 8 & $42.86^{b}$ & $0.063^{a}$ & $0.021^{a}$ & $0.667^{c}$ & & & & \\
\hline - Red-small flower var. & $31^{a}$ & 28 & $9.6^{a}$ & $0.156^{b}$ & $0.181^{b}$ & $-0.161^{a}$ & & & & \\
\hline \multicolumn{11}{|l|}{ Bleberan } \\
\hline - Red-big flower var. & $39^{a}$ & 27 & $30.77^{b}$ & $0.205^{b}$ & $0.285^{c}$ & $-0.390^{a}$ & & & & \\
\hline - Yellow-big flower var. & $36^{a}$ & 34 & $5.56^{a}$ & $0.250^{c}$ & $0.272^{c}$ & $-0.086^{b}$ & & & & \\
\hline - Red-small flower var. & $54^{a}$ & 38 & $29.63^{b}$ & $0.268^{c}$ & $0.327^{c}$ & $-0.218^{a}$ & & & & \\
\hline \multicolumn{11}{|l|}{ Petir } \\
\hline - Red-big flower var. & $2340^{b}$ & 16 & $99.32^{c}$ & $0.138^{b}$ & $0.115^{b}$ & $0.168^{b}$ & & & & \\
\hline - Yellow-big flower var. & $936^{b}$ & 20 & $97.86^{c}$ & $0.202^{b}$ & $0.233^{b}$ & $-0.157^{a}$ & & & & \\
\hline \multirow[t]{2}{*}{ - Red-small flower var. } & $1404^{b}$ & 30 & $97.86^{c}$ & $0.175^{b}$ & $0.172^{b}$ & $0.016^{b}$ & & & & \\
\hline & & & & & & & 0.200 & 0.265 & $6.50 \%$ & $24.41 \%$ \\
\hline F stat. & $0.001^{*}$ & & $0.00005^{*}$ & $0.011^{*}$ & $0.008^{*}$ & 0.261 & & & & \\
\hline$P$ value & $13.540^{*}$ & & $36.930^{*}$ & $7.367^{*}$ & $8.016^{*}$ & 1.617 & & & & \\
\hline \multicolumn{11}{|l|}{ Among floral variants } \\
\hline Red-big flower var. & $2483^{a}$ & 144 & & $0.238^{a}$ & $0.208^{a}$ & $0.125^{a}$ & & & & \\
\hline Yellow-big flower var. & $1042^{a}$ & 118 & & $0.279^{a}$ & $0.237^{a}$ & $0.150^{a}$ & & & & \\
\hline \multirow[t]{2}{*}{ Red-small flower var. } & $1517^{a}$ & 124 & & $0.227^{a}$ & $0.245^{a}$ & $-0.078^{a}$ & & & & \\
\hline & & & & & & & 0.248 & 0.265 & $1.70 \%$ & $6.45 \%$ \\
\hline F stat. & 0.819 & & 0.996 & 0.997 & 0.787 & 0.354 & & & & \\
\hline$P$ value & 0.204 & & 0.003 & 0.002 & 0.246 & 1.166 & & & & \\
\hline \multicolumn{11}{|c|}{$\begin{array}{l}\mathrm{H}_{E}=\text { Hardy-Weinberg expected panmictic heterozygosity, } \mathrm{H}_{O}=\text { observed heterozygosity, } \mathrm{F}_{I S}=\text { mean fixation index } \\
\text { over all loci, the deviation from expected frequencies under Hardy-Weinberg equilibrium, } \mathrm{H}_{S}=\text { heterozygosity within } \\
\text { population, } \mathrm{H}_{T}=\text { total heterozygosity, } \mathrm{D}_{S T}=\text { genetic diversity between population, } \mathrm{G}_{S T}=\text { the mean proportion of } \\
\text { total genetic diversity at polymorphic loci due to differences between population. Clonality refers to the proportion } \\
\text { of vegetative vs. reproductively propagated individuals within populations and floral variants. } F \text { ratios and } P \text { values } \\
\text { resulted from a test of analysis of variance (ANOVA, LSD test) performed among parameters within populations and } \\
\text { within floral variants. Values followed by a different superscript letter within a column for each population and floral } \\
\text { variants are significantly different at } \mathrm{P}<0.05 \text {. Asterisked values indicated significant differences at } P<0.05 \text {. }\end{array}$} \\
\hline
\end{tabular}




\subsection{Controlled pollination: The crossability and reproductive outputs}

Hand-self pollination treatments produced very few reproductive outputs, or even no seeds were produced. Particularly in the population which possessed higher heterozygosity and tended to be more outcrosser, no signs of fertilization were observed in any of the self-pollinated flowers. All flowers were abscissed right after the end of anthesis phase. However, the highly clonalized populations which tended to be more inbreeders were able to produce flowers in hand-self pollination (Figure 2).

The highest level of Reproductive Success (RS) was achieved from interspecific crosspollinated flowers for all variants. The interspecific crossing, a cross-pollination within the same variant, performed the highest level of RS. Particularly in the more genetically diverse populations, the seed sets from the interspecific cross-pollination were even higher than those resulting from the open pollination. However, a very low level of RS was observed in the intra-specific cross-pollination, a crossing between variants. The RSF variant even observed to be incompatible at any of cross-pollination treatments, resulting in $0 \%$ mean of RS. Mature fruits were only observed in the reciprocal crosspollination of $\mathrm{YBF} \times \mathrm{RBF}$ variants.

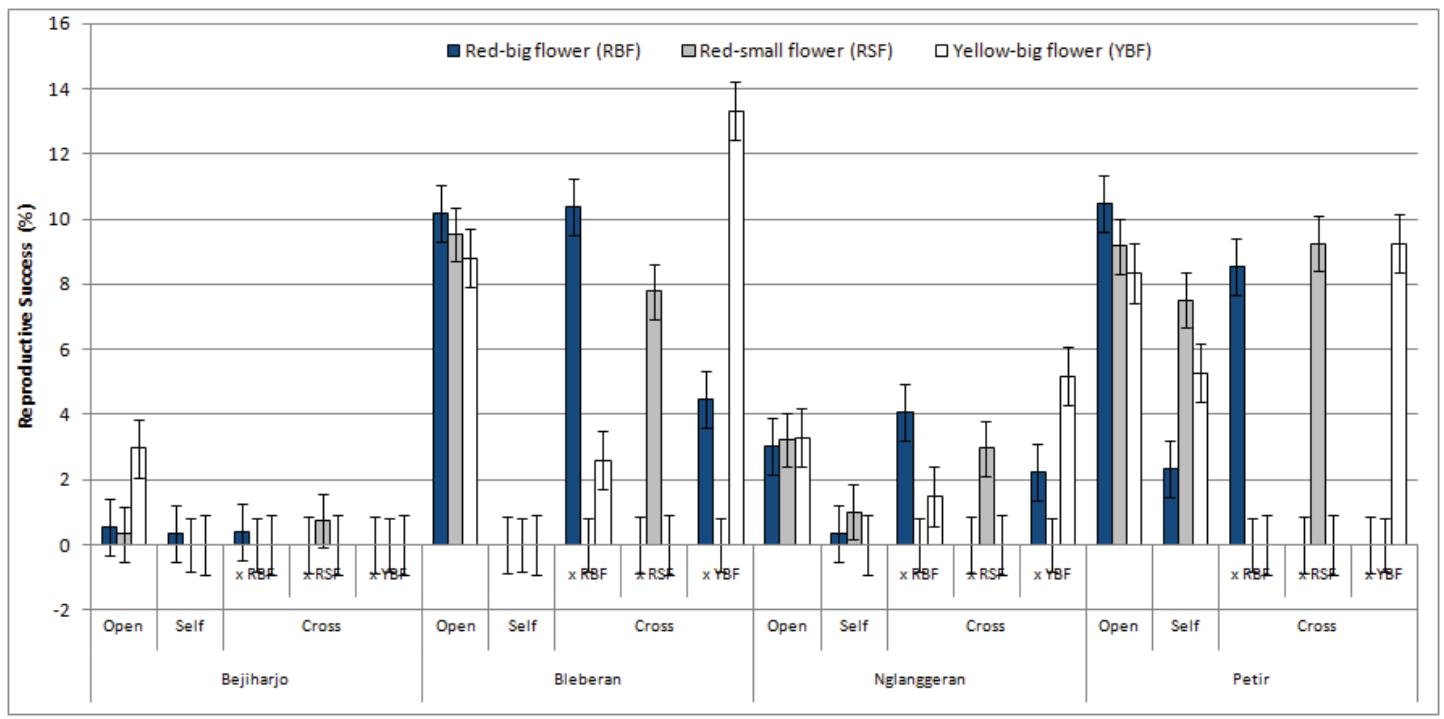

Figure 2: The Reproductive Success (percentage of total seed set to the emerged flowers, \%) for the open, selfed, crossed-inter- and crossed-intra-specific hand pollination, in the red-big flower (RBF, black column), red-small flower (RSF, grey column) and yellow-big flower (YBF, white column) variants, in four populations in Gunung Sewu. Vertical bars represent standard errors.

ANOVA showed no differences in the Reproductive Success among both floral variants and populations. However, a significant Reproductive Success was observed among hand pollination treatments, in which the interspecific cross-pollination always 
resulted in the highest RS. The three of floral variants showed similar cross-ability while reciprocally-crossed to other variants (Table 3).

\section{Discussion}

\subsection{Genetic diversity and mating systems}

Differences in genetic structures were observed among various types of population structures in this study. This finding showed evidence that the more clonalized populations exhibited a much lower level of heterozygosity. However, departure from prediction was reported for some small and isolated populations with the wider genetic base, which tended to have a higher level of genetic diversity and lower fixation index. It is considered that the parental genetic base played a role in maintaining outcrossing within such isolated populations.

TABLE 3: Analysis of variance of the Reproductive Success (\%) resulted from the different pollination treatments, in the red-big flower (RBF), yellow-big flower (YBF) and red-small flower (RSF) variants, in four populations in Gunung Sewu. Asterisked values indicate significant difference at $P<0.05$.

\begin{tabular}{|c|c|c|c|}
\hline & Average & $\mathrm{F}$ & $\mathrm{P}$ \\
\hline \multicolumn{4}{|l|}{ Among floral variants } \\
\hline Red-big flower (RBF) & 1.967 & & \\
\hline Yellow-big flower (YBF) & 2.338 & & \\
\hline \multirow[t]{2}{*}{ Red-small flower (RSF) } & 1.754 & & \\
\hline & & 0.070 & 0.932 \\
\hline \multicolumn{4}{|l|}{ Among sites } \\
\hline Nglanggeran & 1.069 & & \\
\hline Bejiharjo & 0.077 & & \\
\hline Bleberan & 2.587 & & \\
\hline \multirow[t]{2}{*}{ Petir } & 1.831 & & \\
\hline & & 1.902 & 0.139 \\
\hline \multicolumn{4}{|l|}{ Among hand pollination treatments } \\
\hline Open pollination & 0.058 & & \\
\hline Self pollination & 0.014 & & \\
\hline Intra-specific cross-pollination & 0.895 & & \\
\hline \multirow[t]{2}{*}{ Inter-specific cross-pollination } & 5.988 & & \\
\hline & & 18.273 & $0.00000008^{*}$ \\
\hline \multicolumn{4}{|l|}{ Intra-specific crossing among floral variants } \\
\hline Red-big flower (RBF) as female parent & 0.509 & & \\
\hline Yellow-big flower (YBF) as female parent & 0.853 & & \\
\hline \multirow[t]{2}{*}{ Red-small flower (RSF) as female parent } & 0.000 & & \\
\hline & & 1.141 & 0.338 \\
\hline
\end{tabular}


Parental genetic base, which in this study is regarded to the heterozygosity of parent trees, is strongly determined by the proportion of vegetatively vs. reproductively propagated parents in population and their genetic composition. The degree of clonality strongly affected the mating systems and thus determined the level of cross- and self-mating within the population. Since sandalwood has strong ability to reproduce vegetatively by root suckers, thus the landscape features which promote vegetative propagation, such as the rocky and shallow soils, may contribute to the formation of a large portion of root suckers which were genotypically identic, and therefore enhance the level of inbreeding within the population.

Mating systems, which in this study is regarded to the parental inbreeding coefficient, were affected by the degree of parental clonality and heterozygosity. Mean $\mathrm{F}_{I S}$ values indicated that only population undergoes strong clonality were deviated from HardyWeinberg equilibrium, showing a high level of inbreeding and an excess of homozygosity. As also reported in S. insulare, the fixation index $\mathrm{F}$ was positive and significantly different from zero for all the isolated islands [1]. The authors proposed that the assumption of an increased selfing in the isolated populations appeared to be the main explanatory factor. An evolution of the mating system towards self-pollination could result from a lack of pollinators in some islands [15] and lack of outcross-mating partners in the heavily clonalized [5, 6] or lower genetic bases' [1] populations.

In this study, the clonalized populations exhibited lower heterozygosity and tended to be more inbreeders. Studies on other sandals species also reported similar influences of fragmentation and clonality to the mating systems. RFLP-based study on S. spicatum in Western Australia showed that isolated populations are less diverse than bigger populations [2]. The $\mathrm{F}_{I S}$ value which was close to zero $\left(\mathrm{F}_{I S}-0.026\right)$ indicated a random mating, but inbreeding tended to dominate mating in some of the isolated populations [2]. Microsatellite-based study on S. insular in insular Pacific reported that significant excess of homozygosity, indicating a high level of inbreeding, was only observed within isolated islands $\left(\mathrm{H}_{o} 0.28 ; \mathrm{F}_{I S} 0.12 ; 58 \%\right.$ level of clonalities $)$ and not in mainland $\left(\mathrm{H}_{o}\right.$ 0.49; $F_{I S}-0.07$ ), respectively [6]. RAPD-based analysis on five isolated and clonalized populations of S. lanceolatum in south-eastern Victoria, Australia reported a very low heterozygosity $\left(\mathrm{H}_{S}\right.$ 0.06) due to a very high inbreeding depression [5].

Higher gene diversity and outcrossing rate despite the small population size can be partly related to the mating system of the outbreeding plants [28]. The increase of selfing rate, which lowering heterozygosity, may occur in the outbreeding taxa populations which subjected to the low parental genetic base [1,28], strongly clonalized $[3,5,6]$ or isolated condition $[24,29]$. Clonality events may favour high levels of geitonogamy which 
increase the homozygosity. Moreover, a high level of inbreeding in naturally outbreeding taxa may favour population bottlenecks, genetic drift and inbreeding depression [28], such conditions which increase rare and missing alleles [1, 2, 20], reduce heterozygosity $[6,8]$ and reduce reproductive fitness $[18,22]$. Landscape structures regarded to the rock outcrops, slopes, and natural barriers may also lead to the differences of genetic diversity and mating systems [8].

Since sandalwood is naturally an outbreeder, it is hypothesized that it will have less ability to cope with inbreeding depression. However, as a result of selection conformed to "reproductive assurance theory" [24, 29], the small, isolated, clonalized and/or lower genetic bases' populations will be more inbreeder, and therefore will lack the negative effects of inbreeding depression. Both populations which were highly clonalized, the Petir and Bejiharjo, were confirming the "reproductive assurance theory," in which selfing taxa occurred in isolated or clonalized population to enhance the ability for selffertilization. These two clonalized populations were the only populations observed to produce high selfed-seeds, particularly at Petir. Both clonalized populations were also produced very few, even no outcrossed-seeds, in hand cross-pollination. However, a very low number of selfed-seeds produced in Bejiharjo were considered as the effect of the early-acting inbreeding depression. In contrast, the evidence of late-acting inbreeding depression was observed in the bigger population Petir which has been exposed to a clonality condition and therefore has been dominated by the self-mating system, for a relatively longer time period. In this bigger and denser but highly clonalized population, the effect of inbreeding depression will not be expressed until the reproductive outputs reached the seedling level. The success of reproductive at populations which have been subjected to inbreeding for a long time period could be seen as a result of possession of pre-adapted breeding systems, as reported for $C$. euphrasioides in the highland of Andes, Chile [29], S. spicatum in Western Australia [2] and S. australocaledonium in New Caledonia [1].

\subsection{Crossability between sandalwood floral variants}

The hand-pollination experiments in this study indicated that sandalwood is an allogamous and self-incompatible species. Naturally, sandalwood observed to be a highly outcrossed species $[3,16,17]$ with partially [21] or totally [22] self-incompatible. Factors that may reduce or inhibit outcross-pollination processes, therefore, could have considerable effects on reproduction aspects that result in the failure of reproductive processes and thus reducing the reproductive outputs $[8,15]$. 
Intraspecific crossed-pollination in this study resulted in a very low seed sets. The RSF variant even observed to be incompatible at any of cross-pollination treatments. Mature fruits were only observed in the reciprocal cross-pollination of YBF $\times$ RBF variants. Size of the corolla, length of filament and anthers position were positively correlated to the quality of pollen transferred. Hence the heterostylous and heteranthery flowers tended to be more outcrosser [8, 9]. In this study, YBF and RBF possessed similar floral structures: bigger perigonium, longer sexual organs but with shorter longevity, and similar/lower position of the stylus to stamens. Whilst, RSF flowers are the smaller, similar/higher position of the stylus, and possessed longer longevity. In this study, crossing between variants having similar floral structures gained more seed sets. Other study found differences on the size of reproductive structures on twenty-five biotically pollinated plants of the Chaco Serrano Forest, Argentina, that was resulting in the differences of seed sets [7]. The mating systems of narrow endemic Anthirrhinum microphyllum was also strongly related to the characters of sexual organs [8].

A barrier to intermate, which lead to a mating-incompatibility, may also occur as a result of the difference in gene composition [30]. These genetic differences existed as a result of different allele distribution between populations [2]; a case that has also observed in this study in which there were different patterns of allele frequency distribution among sandalwood variants. The existence of genetic differentiation among variants, along with mating incompatibility between variants, has brought clear evidence that population has had subdivided and differentiated into small groups of the population according to the floral variants. This population differentiation and fragmentation may dramatically reduce population size, which along with the genetic differentiation, are the main factors causing inbreeding and restricted gene flow [1-3]. Within-population genetic differentiation, which increases inbreeding and reduces heterozygosity, was also observed with S. spicatum [2] and S. austrocaledonicum [1]. These results on clear clustering of sandal populations suggested that the gene flow and mating opportunities might have been reduced [30]. Studies have also suggested that different pattern of allele frequency distribution [2], a low seed sets and/or restricted gene flow [1, 4] can create such genetic clustering in natural populations. Hence, the extent of the heterozygote deficit could in part be attributed to the lack of sufficient mating partners, which in turn leading to the successive inter-mating between small groups of plants.

The sandalwood floral variants in this study were considered to be classified in the different gene pool according to their inter-mating ability. Some authors proposed classifying each plant and its related species by gene pools rather than by formal taxonomy [30]. Primary gene pool (GP-1) is according to the members of the "probably in the same 
species" that can intermate freely in which crossing and gene transfer is easy, hybrids are generally fertile with good chromosome pairing, and gene segregation is approximately normal. In secondary gene pool (GP-2), the members are probably normally classified as different species to the primary gene pool. However, these species are closely related and can cross and produce at least some fertile hybrids though there are some reproductive barriers. The members of the tertiary gene pool (GP-3) are more distantly related to the primary gene pool. The primary and tertiary gene pools can be intermated, but gene transfer between them is almost impossible.

\section{Conclusion and Recommendation}

Observed heterozygosity varied significantly with sites $\left(\mathrm{H}_{O} 0.021\right.$ to 0.327 ; F stat. 0.008 , $P$ value 8.016; respectively). A moderate level of diversity was maintained among sites $\left(\mathrm{H}_{S}\right.$ 0.200; $\mathrm{H}_{T} 0.265 ; \mathrm{D}_{S T}=6.5 \% ; \mathrm{G}_{S T}=24.41 \%$, respectively). The more clonalized populations exhibited a much lower level of heterozygosity and tended to be more inbreeder. The $\mathrm{F}_{I S}$ values, which represented the parental inbreeding coefficient, were also differed among sites in line with the differences in heterozygosity and the degree of clonality. However, there were no significant differences in heterozygosity among floral variants $\left(\mathrm{H}_{O} 0.227\right.$ to 0.279 ; $\mathrm{F}$ stat. 0.787 , $\mathrm{P}$ value 0.246 ; respectively). Some of diversity was maintained among variants $\left(\mathrm{H}_{S} 0.248 ; \mathrm{H}_{T} 0.265 ; \mathrm{D}_{S T}=1.7 \% ; \mathrm{G}_{S T}=6.45 \%\right.$, respectively).

No differences found on the Reproductive Success among both floral variants and populations. However, a significant Reproductive Success was observed among hand pollination treatments. The highest level of Reproductive Success (RS) was achieved from interspecific cross-pollinated flowers for all variants. However, a very low level of RS was observed in the intraspecific cross-pollination. The RSF variant even observed to be incompatible at any of cross-pollination treatments. Mature fruits were only observed in the reciprocal cross-pollination of YBF $\times$ RBF variants. The population with higher heterozygosity and more outcrosser failed to produce seeds in hand-self pollination. However, the highly clonalized populations which tended to be more inbreeders were able to produce flowers in hand-self pollination.

Differences in floral structures, as well as the genetical differentiation, might have considerable effects on the success of reproductive processes. The hand-pollination experiments in this study clearly indicate that sandalwood is an outcrossing, allogamous and self-incompatible species. Hence, sexual reproductive failure was considered a result of inbreeding depression due to a very low genetic base and/or the strong 
clonality. Maintaining the evolutionary processes within each population should be carried out with a different strategy according to the genetic diversity, degree of clonality and the composition of floral variants in the population. Some of small, fragmented sandalwood plantations in Gunung Sewu are tending towards clonality; and the substructuring of the population was strengthened by the occurrence of three different variants that were failed to intermate each other. The fragmentation of these populations into small stands of almost identic genotypes, exhibiting little or no sexual reproduction, suggests a need for a broader conservation strategy. In order to maintain local adaptations that contribute to the adaptive diversity of the species, it is recommended to conduct enrichment planting and facilitate natural regeneration by sexual reproduction in each of floral variants. Restoring the population by replanting areas is using the same variants, but with the broader genetic base, and also recommended. Since then, variants were considered to be classified in different gene pool due to its difference on floral structures, allele distribution, and crossability; and supposed to be managed under a different management unit.

\section{Acknowledgment}

These results are part of long-term research on sandalwood genetic conservation and improvement; which is supported by the grant of Hibah Peningkatan Kapasitas Peneliti Dosen Muda year 2016 by the Universitas Gadjah Mada in the grant number. 1613/UN1P.III/LT/DIT-LIT/2016. The laboratory work and analyses were done in the Genetics Laboratory of Silviculture Department, Universitas Gadjah Mada in Yogyakarta, Indonesia, and many thanks to Professor Mohammad Na'iem as the head of the laboratory. Many thanks go to Untung Maryanto for laboratory work, and Sunar (Bejiharjo), Andiyanto (Nglanggeran), Kustini (Bleberan), and Suparsono (Petir) for field assistances.

\section{References}

[1] Bottin L, Tassin J, Nasi R, Bouvet J. Molecular, quantitative and abiotic variables for the delineation of evolutionary significant units: case of sandalwood (Santalum austrocaledonicum Vieillard) in New Caledonia. Conserv Genet. 2007. 8 (1):99-109. https://link.springer.com/article/10.1007/s10592-006-9152-7

[2] Byrne M, MacDonald B, Broadhurst L, Brand J. Regional genetic differentiation in Western Australian sandalwood (Santalum spicatum) as revealed by nuclear RFLP analysis. Theor Appl Genet 2003. 107:1208-1214. https://link.springer.com/content/ 
pdf/10.1007/s00122-003-1365-2.pdf

[3] Dani KGS, Ravikumar P, Kumar RP, Kush A. Genetic variation within and among small isolated populations of Santalum album. Biologia Plantarum 2011. 55 (2): 323-326. https://pubag.nal.usda.gov/catalog/416757

[4] Rao MN, Ganeshaiah KN, Shaanker RU. Assessing threats and mapping sandal resources to identify genetic 'hot-spot' for in-situ conservation in peninsular India. Conserv Genet 2007. 8: 925-935. https://link.springer.com/article/10.1007\% 2Fs10592-006-9247-1

[5] Wolf PG, Campbell DR, Waser NM, Sipes SD, Toler TR, and Archibald JK. Tests of pre- and postpollination barriers to hybridization between sympatric species of Ipomopsis (Polemoniaceae). Am J Bot. 2001. 88(2): 213-219. https://www.ncbi.nlm. nih.gov/pubmed/11222244

[6] Lhuillier E, Butaud JF, Bouvet JM. Extensive clonality and strong differentiation in the Insular Pacific tree Santalum insulare: implications for its conservation. Ann Bot 2006. 98: 1061-1072. https://www.ncbi.nlm.nih.gov/pmc/articles/PMC3292246/

[7] Fernandez VA, Galetto L, Astegiano J. Influence of flower functionality and pollination system on the pollen size-pistil length relationship. Organisms, Diversity \& Evolution. 2009. 9: 75-82. https://www.sciencedirect.com/science/article/pii/ S1439609209000038

[8] Warburton CL, James EA, Fripp YJ, Trueman SJ, Wallace HM. Clonality and sexual reproductive failure in remnant populations of Santalum lanceolatum (Santalaceae). Biological conservation 2000. 96 (1): 45-54. http://research.usc.edu.au/vital/access/ manager/Repository/usc:872

[9] Wolf PG, Campbell DR, Waser NM, Sipes SD, Toler TR, and Archibald JK. Tests of preand postpollination barriers to hybridization between sympatric species of Ipomopsis (Polemoniaceae). Am J Bot. 2001. 88(2): 213-219. http://onlinelibrary.wiley.com/doi/ 10.2307/2657012/abstract

[10] IUCN. Asian Regional Workshop on Conservation \& Sustainable Management of Trees, Viet Nam, August 1996. Santalum album. The IUCN Red List of Threatened Species. 1998:1-4. http://dx.doi.org/10.2305/IUCN.UK.1998.RLTS. T31852A9665066.en.

[11] da Silva JAT, Page T, Zhang X, Kher MM, Nataraj M, Soner D, Ma G. Sandalwood: basic biology, tissue culture, and genetic transformation. Planta 2016. 243: 847-887. https://www.ncbi.nlm.nih.gov/pubmed/26745967

[12] Indrioko S and Ratnaningrum YWN. Habitat loss caused clonality, genetic diversity reduction and reproductive failure in Santalum album (Santalaceae), an endangered 
endemic species of Indonesia. Proc Env Sci. 2015. V: 613-620. https://www. sciencedirect.com/science/article/pii/S1878029615002893

[13] Haryono E and Suratman. Significant features of Gunung Sewu Karst as geopark site. Proceeding on 4th International UNESCO Conference on Geopark, April 12-15, 2010. Langkawi, Malaysia. 2010: 1-9. http://www.academia.edu/2559967/ Significant_features_of_Gununsewu_Karst_as_Geopark_Site

[14] Sindhu-Veerendra, HC and Anantha-Padmanabha HS. The breeding system in Sandal (Santalum album L.). Silvae Genetica. 1996. 45 (4): 188-190. https://www.researchgate.net/publication/ 286758350_The_breeding_system_in_sandal_Santalum_album_L

[15] Barrett SCH, Baker AM, Jesson LK. Mating strategies in Monocotyledons. Monocots Newsletter II. Depertment of Botany, University of Toronto. Ontario, Canada; 2006: 258-269 http://labs.eeb.utoronto.ca/barrett/pdf/SCHB_175.pdf

[16] Suma TB, Balasundaran M. Isozyme variation in five provenances of Santalum album in India. Aust J Bot 2003. 51(3): 243-249. http://www.publish.csiro.au/BT/BT02094

[17] Rughkla A, McComb JA, and Jones MGK. Intra-and inter specific pollination of Santalum spicatum and S. album. Aust J Bot. 1997. 45(6): 1083-1095. http://www. publish.csiro.au/BT/BT96079

[18] Torres E, Iriondo JM, and Perez C. Vulnerability and determinants of reproductive success in the narrow endemic Antirrhinum microphyllum (Scrophulariaceae). Am J Bot. 89, 2002. (7): 1171-1179. http://onlinelibrary.wiley.com/doi/10.3732/ajb.89.7.1171/ abstract

[19] Herawan T, Na'iem M, Indrioko S, Indrianto A. Somatic embryogenesis of Sandalwood (Santalum album L.). Indonesian Journal of Biotechnology. 2014. Vol. 19, No. 2 , pp.168-175. https://jurnal.ugm.ac.id/ijbiotech/article/view/9311

[20] Ratnaningrum YWN and Indrioko S. Response of flowering and seed production of sandalwood (Santalum album linn., Santalaceae) to climate changes. Proc Env Sci. 2015. V: 665-675. https://www.sciencedirect.com/science/article/pii/ S187802961500290X

[21] Ratnaningrum YWN and Indrioko S. Variation on genotypes and flowering characters affecting pollination mechanisms of sandalwood (Santalum album Linn., Santalaceae) planted on ex-situ gene conservation in Yogyakarta, Indonesia. Eur J For Res. 2014. VI: 167-179. https://eprints.lib.hokudai.ac.jp/dspace/handle/2115/56853

[22] Tamla HT, Cornelius JP, Page T. Reproductive biology of three commercially valuable Santalum species: development of flowers and inflorescences, breeding systems, and interspecific crossability. Euphytica 2012. 184:323-333. https://researchonline. jcu.edu.au/20127/ 
[23] Applegate GB, Davis AGW, Annable PA. Managing sandalwood for conservation in North Queensland, Australia. Proceedings of the Symposum on Sandalwood in the Pacific, Honolulu, Hawaii, USDA Forest Service. 1990:12-18. https://www.fs.usda.gov/ treesearch/pubs/27489

[24] Herlihy CR and Eckert CG. Evolution of self-fertilization at geographical range margins? A comparison of demographic, floral, and mating system variables in central vs. peripheral populations of Aquilegia canadensis (Ranunculaceae). Am J Bot 2005. 92(4): 744-751. https://www.ncbi.nlm.nih.gov/pubmed/21652454

[25] Frankham R, Ballou JD, and Briscoe DA. Introduction to Conservation Genetics. Cambridge University Press. Cambridge; 2002. p. 617. https://trove.nla.gov.au/work/ 4009564?selectedversion=NBD22591538

[26] Owens JN, Sornsathapornkul P, Thangmitcharoen S. Studying flowering and seed ontogeny in tropical forest trees. ASEAN-Canada Forest Tree Seed Centre. Muaklek, Saraburi 18180, Thailand; 2001. p. 134. http://agris.fao.org/agris-search/search. do?recordID=XF2016045131

[27] Simanjuntak T. Gunung Sewu in prehistoric times. Gadjah Mada University Press. Yogyakarta, Indonesia; 2002. p. 296. https://books.google.co.id/books/about/ Gunung_Sewu_in_Prehistoric_Times.html?id=onKBAAAAMAAJ\&redir_esc=y

[28] Dudash MR and Fenster CB. The role of breeding system and inbreeding depression in the maintenance of an outcrossing mating strategy in Silene virginica (Caryophyllaceae). Am J Bot 2001. 88 (11): 1953-1959. https://www.ncbi.nlm.nih.gov/pubmed/ 21669628

[29] Arroyo MTK, Munoz MS, Henríquez C, Till-Bottraud I, Perez F. Erratic pollination, high selfing levels and their correlates and consequences in an altitudinally widespread above-tree-line species in the high Andes of Chile. Acta Oecologica 2006. 30: 248257. https://www.sciencedirect.com/science/article/pii/S1146609X0600066X

[30] Harlan JR and Wet, JMJ. Toward a rational classification of cultivated plants. Taxon 1971. 20 (4): 509-517. https://www.jstor.org/stable/1218252 